\title{
Evaluation of in vivo wound healing activity of Moroccan Citrus reticulata peel extract
}

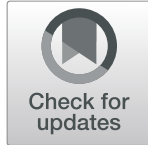

Sanae Dahmani ${ }^{1,2^{*}}$ (D) Rachida Chabir ${ }^{2}$, Faouzi Errachidi ${ }^{3}$, Wiam Berrada ${ }^{3}$, Hafsa Lansari ${ }^{2}$, Meryem Benidir ${ }^{3}$, Lahsen El Ghadraoui ${ }^{3}$ and Abdellatif Bour ${ }^{1}$

\begin{abstract}
Background: Citrus reticulata is one of the most cultivated fruit with great benefits for humans in the world. Citrus reticulata peel has several biological activities within them hypoglycemic, hepatoprotective, antimicrobial and antioxidant. The present study emphasizes on the in vivo wound healing and in vitro antimicrobial and antioxidant activities of Citrus reticulata peel extract.
\end{abstract}

Methods: Forty albino mice (23-29 g) of either sex were divided into four groups. The test groups were treated with experimental ointment ( $0.5 \%$ and $10 \%$ of methanolic extract), negative control were treated with Vaseline and the positive control were treated with silver sulfadiazine. Burn wounds were induced on dorsal area of mice bodies. Wound area measurement was carried out every day during 22 days. Biochemical screening was performed to identify possible compounds. Antioxidant and antimicrobial activities were also determined.

Results: Significant wound healing activity was observed with topical application of Citrus reticulata peel extract. Wound area reduction at day 16 of treatment was $100 \%$ for both treated groups $(0.5 \%$ and $10 \%)$ when compared to positive and negative control it was $100 \%$ and $98.32 \%$ respectively at day 22 . Furthermore higher rate of wound contraction (100\% on 16th day) was observed for both treated groups.

The result of biochemical screening showed that $C$. reticulata peel is characterized by highest amount of total polyphenols $(13.19 \mathrm{mg} / \mathrm{g})$, flavonoids $(4.07 \mathrm{mg} / \mathrm{g})$, vitamin C (13.20 mg/g), carotenoids $(0.032 \mathrm{mg} / \mathrm{g})$ and lowest content of macronutrients (Proteins: $0.40 \%$, reducing sugars: $7.21 \%$; lipids: $1.5 \%$ ). Additionally C. reticulata peel exhibited remarkable antioxidant activity using DPPH and phosphomolybdate methods as well as the extract possess antimicrobial effect against pathogen bactria.

Conclusion: The findings from this research indicated that Citrus reticulata peel extract is effective in inhibiting the growth of pathogen bacteria and could be of therapeutic potentials for wound healing.

Keywords: Citrus reticulata, Wound healing activity, Methanolic extract, Pathogen bactria, Mice

\footnotetext{
* Correspondence: dahmani.sanae@hotmail.fr

'Laboratory of Biological Testing, Team of Food and Nutrition Transition,

Faculty of Sciences, Ibn Tofail University BP 133, 14000 Kenitra, Morocco

'Laboratory of HumanPathology, Biomedicine and Environment, Team of

Nutrition, Agri-Food and Environment, Faculty of Medicine and Pharmacy,

Sidi Mohamed Ben Abdelah University, Km 2200 Road of Sidi Hrazem, BP

1893 Fez, Morocco

Full list of author information is available at the end of the article
}

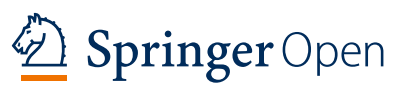

(c) The Author(s). 2020 Open Access This article is licensed under a Creative Commons Attribution 4.0 International License, which permits use, sharing, adaptation, distribution and reproduction in any medium or format, as long as you give appropriate credit to the original author(s) and the source, provide a link to the Creative Commons licence, and indicate if changes were made. The images or other third party material in this article are included in the article's Creative Commons licence, unless indicated otherwise in a credit line to the material. If material is not included in the article's Creative Commons licence and your intended use is not permitted by statutory regulation or exceeds the permitted use, you will need to obtain permission directly from the copyright holder. To view a copy of this licence, visit http://creativecommons.org/licenses/by/4.0/. 


\section{Background}

Plants and their extracts were used as traditional medicine to treat diseases throughout history due to many chemical compounds that they possess. Therefore, extracts obtained from plants have been a source of biologically active compounds and used for healing various diseases. The World Health Organization (WHO) estimated that $80 \%$ of the global population depends on traditional herbal medicines as primary health care. Secondary plant metabolites exhibited interesting biological effects. They have been described as anticancer, antimicrobial, antioxidant, in addition to antiviral and antiparasitic agents [1].. Citrus (Rutaceae family) is one of the most popular world fruit crops; Morocco has an enormous diversity of citrus genetic resources, among the cultivated species, Citrus reticulata (Clementine) is the most important commercial fruit. Citrus fruits are principally consumed as juice or desserts. Citrus processing industries create considerable quantities of byproducts (50\% of the fruit), which includes peels, seeds and pulp [2]. Citrus peels are rich in potential components like flavonoids, vitamin $\mathrm{C}$, carotenoids, dietary fibres and essential oils; they are known for their pharmacological properties and health benefits $[3,4]$.

Burns are a major public health problem causing high morbidity and mortality rate worldwide, it is the result of disruption of normal anatomical structure and functional integrity. Recently, many studies have reported about wound healing, but these have not been at the desired level yet. Several medicinal plants are used in the folk medicine for their wound healing potential such as, Centella asiatica, and Telephium imperati (L.) $[5,6]$. They are widely favored due to their safety, low cost and easy access [7].

Wound healing is promoted by bioactive principles such as triterpenes, alkaloids, and biomolecules, which are in several plant natural products. These agents usually influence one or more phases of the healing process [8], also it involves many cell types such as blood cells, extracellular matrix (ECM), soluble mediators and parenchyma cells [9]. This natural phenomenon can be classified into three main overlapping phases: Inflammation, proliferation and remodeling $[10,11]$. Inflammation is a vascular and cellular reaction, during this stage the injured blood vessel contracts leading to clot formation in order to reduce and slow blood loss. The vasoconstriction is then followed by a vasodilation to provide increased blood flow to the injured site. This vasodilation results in the characteristic signs and symptoms of inflammation such as erythema, heat, oedema, pain and functional disturbances [12]. Proliferative phase is characterized by the activation of macrophages [13], granulation tissue formation, growth of new blood vessels (angiogenesis), in addition to synthesis of collagen by fibroblasts, epithelialization and wound contraction [14]. Remodeling or maturation is the last phase that starts around 3 weeks, the levels of collagen production and degradation tend to be equilibrated. Collagen which is an extracellular protein is remodelled from type III to type I. As scar maturation occures during the remodelling phase, depostion of large collagen bundles take place which provides integrity and strength to the wound tissues. Moreover, Collagen synthesis rate increased after wound healing and its breakdown liberated free hydroxyproline and its peptides $[15,16]$. This phase may last up to a year or more after injury $[17,18]$.

To our best knowledge, no data have yet been carried out on the evaluation of wound healing activity of Citrus reticulata peel extract. The aim of the present study is to evaluate the wound healing potential, antioxidant and antimicrobial activities of $C$. reticulata peel extract used as source of biomolecules.

\section{Materials and methods Animals}

Forty Albino mice (23-29g) of either sex (12 females and 28 males) were obtained from the central animal house of Faculty of Sciences and Technologies, FezMorocco. The animals were housed in individual cages under controlled conditions of temperature $\left(26 \pm 1{ }^{\circ} \mathrm{C}\right)$, relative humidity $(45-55 \%)$ and light $(12 \mathrm{~h}$ light $/ 12 \mathrm{~h}$ dark cycle) with access to standard diet and water for 1 week before and during the experiments. All animals used in this study were cared for and treated humanely following international guidelines.

\section{Plant material}

Citrus reticulata was procured from local market (Fez). The plant was identified and authenticated at Biology Department in the Faculty of Sciences and Technologies, Sidi Mohamed Ben Abdellah University, Fez, Morocco with voucher specimen number V 5. Mature fruits were washed, wiped and peels were separated and cut into small parts. Peel was dried at $40^{\circ} \mathrm{C}$ for $48 \mathrm{~h}$, grounded to fine powder and stored until use.

\section{Extracts preparation}

After comparative study, methanol was selected as suitable solvant for phenolic compounds and flavonoids qualitatively and quantitatively, since it is well known to be an effective solvent for phenolic and flavonoid extraction [19].

C. reticulata peel extracts were obtained by maceration using method developed by Ennajar et al. (2009) [20]. Dried and finely ground peels $(10 \mathrm{~g})$ were extracted by stirring with $100 \mathrm{ml}$ of methanol $80 \%$ at room temperature for three consecutive days. Extracts were filtered through Whatman paper 5 and evaporated under reduced pressure at $50^{\circ} \mathrm{C}$ by a rotary evaporator and the 
crude drug to extract ratio was 2.24:1. Extracts were placed in a dark bottle, and stored at $-8^{\circ} \mathrm{C}$ until further analysis.

\section{Biochemical analysis}

Phenolic compound of $C$. reticulata peel extracts was determined using Folin-Ciocalteau reagent according to the method reported by Barro et al. (2007) [21]. Moreover, flavonoids were evaluated spectrophotometrically using a method based on the formation of a flavonoidaluminium [22]. Also, vitamin C content was determined following a method described previously by Barros et al. (2011) [23] and carotenoids content was carried out according to Lee et al. (2001) [24]. Protein was estimated with the method of Kumar et al. (2013) [25]. Lipid content was measured using extraction with some modifications [26] and reducing sugar content was determined according to the method of Ellouze et al. (2011) [27].

\section{In vitro activities of bioactive extract Radical scavenging activity}

The effect of extracts on the 2,2-diphenyl-1-picrylhydrazyl (DPPH) radical was conducted according to Loizzo et al. (2009) with minor modifications [28]. For the extract, serial dilutions were prepared from a solution of $4 \mathrm{mg} / \mathrm{ml}$ prepared in methanol. Then, $1 \mathrm{ml}$ of each dilution was added to $3 \mathrm{ml}$ of DPPH in methanol $(75 \mu \mathrm{mol} / \mathrm{l})$.

After reacting for $30 \mathrm{~min}$ in dark, mixture was measured at $517 \mathrm{~nm}$ against blank (without DPPH radical). All tests were run in triplicate and the mean values were calculated. BHA was used as a positive control.

$$
\text { Antioxydant activity }(\%)=\left(\frac{A_{\text {control }}-A_{\text {sample }}}{A_{\text {control }}}\right) \times 100
$$

Where $A_{\text {control }}$ is the absorbance of the control and $A_{\text {sample }}$ is the absorbance of the sample.

\section{Total antioxidant capacity}

Total antioxidant capacity of extract was determined by phosphomolybdate method using ascorbic acid as a standard [29]. The tubes containing a mixture of extract solutions $(100 \mu \mathrm{l})$ and $1 \mathrm{~mL}$ of reagent $(0.6 \mathrm{M}$ sulfuric acid, $28 \mathrm{mM}$ sodium phosphate, and $4 \mathrm{mM}$ ammonium molybdate) were incubated in a boiling water bath at $95^{\circ} \mathrm{C}$ for $90 \mathrm{~min}$. After cooling, the absorbance of the solution was measured at $695 \mathrm{~nm}$. The antioxidant capacity was expressed as equivalents of ascorbic acid.

\section{Antimicrobial activity}

In vitro antimicrobial susceptibility test of $C$. reticulata peel extract was done using serial concentrations of $50,100,150$, and $200 \mathrm{mg} / \mathrm{mL}$ [30] against three human pathogenic bacteria: Staphylococcus aureus (ATCC
29213), Enterococcus feacalis (ATCC 51299)), Escherichia coli (ATCC 25922) and one yeast species Candida tropicalis (ATCC 2091) obtained from Laboratory of Functional Ecology and Environment, Faculty of Sciences and Technologies, Fez-Morocco.

\section{Ointment formulation}

Ointment was prepared using distilled water $(5 \mathrm{~mL}), 20$ drops of tween 80 and vaseline $(9 \mathrm{~g})$. Two concentrations of ointment were prepared namely $0.5 \%$ and $10 \%$ of phenolic extract of $C$. reticulata. All the ingredients were melted over a water bath with constant stirring until they became homogeneous. To prepare methanolic extract ointment, $0.025 \mathrm{~g}$ and $0.5 \mathrm{~g}$ of the extract were incorporated into portion of sample ointment base to prepare $0.5 \%$ and $10 \%(\mathrm{w} / \mathrm{w})$ ointment respectively. Finally, extract ointment was transferred to a clean container for topical application during the experiment.

\section{Wound healing studies}

Mice were divided into four groups containing ten animals each ( 3 females and 7 males). The first was the negative control treated with Vaseline, the second was the positive control treated with silver sulfadiazine. The third and fourth groups were treated with methanolic extracts of C. reticultata peel at $0.5 \%(\mathrm{w} / \mathrm{w})$ and $10 \%(\mathrm{w} /$ w) respectively.

All the animals in each group were anaesthetized by open mask method using ether and burn wounds were created on the dorsal part of the animal using a metal rod $\left(2 \mathrm{~cm}\right.$ diameter) heated to $85^{\circ} \mathrm{C}$ and applied on the skin for 20s [31].

\section{Wound area measurement}

A tracing paper and a gauge were used to measure the wound size every day during 22 days after wound. The percentage reduction of the burned area during the study was calculated using the following formula [32]:

$$
\%=\frac{S_{0}-S_{n}}{S_{0}} \times 100
$$

Sn: burned area in $\mathrm{mm}^{2}$ at day $\mathrm{n}$. S0: burned area in $\mathrm{mm}^{2}$ at day 0 .

\section{Hydroxyproline determination}

According to (Tung and Cheng 1969) [33], $50 \mathrm{mg}$ of dried granulation tissue will be hydrolysed in $6 \mathrm{~N} \mathrm{HCl}$ in a test tube for $22 \mathrm{~h}$ at $110^{\circ}$ on boiling water. Then the hydrolysate was cooled and $10 \mathrm{~N} \mathrm{NaOH}$ using phenolphthalein as an indicator was added to neutralize excess acid. The neutral hydrolysate was diluted with distilled water to a concentration of $20 \mathrm{mg} / \mathrm{mL}$ which was used for the estimation of hydroxyproline. Hydroxyproline 
content was calculated from a linear standard curve. To each tube, $0.3 \mathrm{~mL}$ each of hydrolysate, $2.5 \mathrm{~N} \mathrm{NaOH}$, $0.01 \mathrm{M} \mathrm{CuSO} 4$, and $6 \% \mathrm{H}_{2}{ }^{2} \mathrm{O}_{2}$ were added. Tube were placed in water bath at $75{ }^{\circ} \mathrm{C}$. After $10 \mathrm{~min}$, tubes were cooled for $5 \mathrm{~min}$ in cold water. $1 \mathrm{ml}$ of this solution is transferred into $50 \mathrm{ml}$ tube to which 1-propanol and the oxidant solution was added, then the content of the tube was mixed for $4 \mathrm{~min}$. After that the test tubes were further incubated for $25 \mathrm{~min}$ at $60{ }^{\circ} \mathrm{C}$. Absorbance was measured at $558 \mathrm{~nm}$ within 2-3 h. Hydroxyproline content was calculated from a linear standard curve.

\section{Statistical analysis}

The results were performed using ANOVA one-way for determining the significant difference and expressed as mean \pm SD. A probability value of $p \leq 0.05$ was considered significant. The inter group significance was analysed using Dunnet's t-test. All the statistical analysis and data presentation were done using GraphPad Prism version 7.Ink.

\section{Results and discussion}

Biochemical characterization of Citrus reticulata methanolic extract

The outcomes of biochemical composition (Table 1) showed that fruit peel of Citrus reticulata is rich in antioxidants such as phenolic compounds (13.19 mg GAE/g DW), flavonoids (4.07 mg QE/g DW), vitamin C (13.20 $\mathrm{mg} / \mathrm{g} \mathrm{DW}$ ) and carotenoids (3.23 mg/g DW).

Wang et al. (2016) [34] have reported total phenolic content of $14.60 \mathrm{mg}$ GAE/g DW from C. reticulata peel extract, which were similar to present results. However, it was much lower than those found by Zhang et al. (2018) (22.80 to $32.76 \mathrm{mg}$ GAE/g DW) [35], but was higher than those reported by Chen et al. (2010) (about $0.6 \mathrm{mg}$ GAE/ g DW) [36].

Flavonoids are a large group of phenolic secondary metabolites that are widespread in plants and have many biological activities [37, 38]. Zhang et al. (2018) [35] found that the flavonoid contents in peel ranged from

Table 1 Biochemical characterization of Citrus reticulata peel extract

\begin{tabular}{lc}
\hline Micronutrients (mg/g) & $13.20 \pm 0.1$ \\
Vitamin C & $0.032 \pm 0.03$ \\
Carotenoids & $13.19 \pm 0.01$ \\
Polyphenols & $4.07 \pm 0.27$ \\
Flavonoids & \\
Macronutrients (\%) & $0.40 \pm 0.01$ \\
Proteins & $7.21 \pm 0.01$ \\
Reducing sugars & $1.5 \pm 0.07$ \\
\hline Lipids & \\
\hline
\end{tabular}

The results were expressed as mean \pm SD $(N=3)$
23.29 to $56.52 \mathrm{mg} \mathrm{RE} / \mathrm{g} \mathrm{DW}$, which were higher to our results.

Vitamins are essential organic compounds which are involved in fundamental functions of the body such as growth, maintenance of health and metabolism [39]. Our values of vitamin C reflect highest amount than those published by Barros et al. (2012) $(2.80 \mathrm{mg} / \mathrm{g} \mathrm{DW})$ [40]. On the other side the total carotenoid contents of the present study are lower than those found by Wang et al. (2008) [41] who reported that the carotenoid contents of $C$. reticulata peel extract was $2 \mathrm{mg} / \mathrm{g}$ DW.

Concerning macronutrients, proteins, sugars and lipids are essential for health maintenance, growth of body tissues, reproduction, immunity, and healing [42].

From Table 1, it was found that the amount of reducing sugars in C. reticulata peel extract was $7.21 \%$ DW, which is in agreement with result published by Lovina and Kaushal 2018 [43], additionnaly protein and lipid contents determined in our study were 0.40 and $1.5 \%$ DW respectively. These outcomes are lower than that found by Ghanem et al. (2012) [44] and Lovina and Kaushal (2018) [43].

These differences in the levels of nutritional and antioxidant compounds in citrus peels could be attributed to pedoclimatic factors (soil type, sun exposure and precipitation), genetic factors (variety), agricultural factors (organic farming, tree fruit production, the state of maturation, growing area, fertilization, irrigation) (Causse et al., 2007) [45] and analytical methods [46].

\section{Antioxidant capacity}

Owing to the complex composition of phytochemicals, the antioxidant activities of plant extracts were evaluated using two or more methods. The DPPH radical scavenging and Phosphomolybdate tests were used to evaluate the antioxidant activity of citrus peel extract. Antioxidant activity of peel extract expressed as $\mathrm{IC}_{50}$ value and total antioxydant capacity were presented in Table 2. A low $\mathrm{IC}_{50}$ value represents strong antioxidant activity.

Citrus reticulata peel extract demonstrated strong $\mathrm{DPPH}$ radical scavenging activity with an $\mathrm{IC}_{50}$ value of $0.11 \mathrm{mg} / \mathrm{mL}$ and total antioxidant capacity of $15.71 \mathrm{mg} / \mathrm{g}$ EAA at $0.4 \mathrm{mg} / \mathrm{Ml}$ (Table 2).

Table 2 Radical scavenging activity and total antioxydant capacity of Citrus reticulata peel extract

\begin{tabular}{lccc}
\hline & \multicolumn{3}{c}{ Methods } \\
\cline { 2 - 3 } & \multicolumn{2}{c}{ DPPH } & PPM \\
\cline { 2 - 3 } & $\begin{array}{c}\text { \% Antioxidant } \\
\text { activity }\end{array}$ & $\mathbf{I C}_{\mathbf{5 0}}(\mathbf{m g} / \mathbf{m l})$ & mg/g EAA \\
\hline C. reticulata peel extract & $94.35 \pm 0.02$ & $0.11 \pm 0.01$ & $15.71 \pm 0.005$ \\
BHA & $98.45 \pm 0.00$ & $0.0125 \pm 0.00$ & - \\
\hline
\end{tabular}

The results were expressed as mean $\pm \mathrm{SD}(N=3)$ 
Our results revealed higher antioxydant activity than reported by Ghasemi et al. (2009) [47] and Chen et al. (2017) [48]. Phenolic compounds has been shown to be the major contributor of the oxygen radical absorbance capacity in fruits. Some studies have reported a correlation between the antioxidant capacity and phenolic compounds content $[49,50]$.

\section{Antimicrobial activity}

Methanolic extract of $C$. reticulata showed significant antibacterial activity against both gram positive (Enterococcus feacalis (ATCC 51299), and skin bacteria Staphylococcus aureus (ATCC 29213)) and gram negative (Escherichia coli (ATCC 25922)) bacteria, showing zone of inhibition $\geq 8.5 \mathrm{~mm}$, at $200 \mathrm{mg} / \mathrm{mL}$, whereas no inhibition zone was observed for Candida tropicalis (ATCC 2091).

In the present study, $C$. reticulata peel extract revealed good antibacterial activity against various pathogenic bacteria, similar to that noticed in a number of studies $[51,52]$ which seemed to have beneficial effects on wound healing.

\section{Wound healing activity of $C$. reticulata peel extract}

The present study was undertaken to assess the wound healing effect of $C$. reticulata methanolic extract in experimentally induced wounds in mice.

At the beginning, average burn surfaces were homogeneous between the four groups. The animals in the treated groups $(0.5 \%$ and $10 \%)$ showed a non-significant reduction of the wound area compared to the positive group, throughout the study. However, a significant improvement of wound-healing activity was observed in the treated groups $(0.5 \%$ and $10 \%)$, compared to the negative group treated with Vaseline from the 22th day $(P \leq 0.05)$ (Fig. 1).

On the 16th day, the percentages of burned area reduction for both treated groups $(0.5 \%$ and $10 \%)$ were $100 \%$, compared to the positive control this percentage $(100 \%)$ was reached on the last day (day 22), on the other hand the percentages of reduction in negative control was $98.32 \%$ (Fig. 2).

Results obtained in the present study proved that percentage of wound contraction in the negative control was 5.95\% to $33.62 \%$ from day 7 to day 14 and $67.50 \%$ to $90.83 \%$ from day 16 to day 22, while complete epithelization and healing were observed on day 26. In positive group, percentage of wound contraction was $20.24 \%$ to $37.12 \%$ from day 7 to day 14 and $76.77 \%$ to $100 \%$ from day 16 to day 22 .

The percentage of wound contraction in groups treated with $0.5 \%$ and $10 \%$ ointment was $57.09 \%$ to $64.39 \%$ and $45.13 \%$ to $87.62 \%$ respectively from day 7 to day 14 , while complete epithelization and healing were observed on day 16 for both groups (Fig. 3).

Our research showed a significant increase in total protein and hydroxyproline content in granulation tissue collected from mice treated with both doses of $C$. reticulata extract $(0.5 \%$ and $10 \%)$ and positive control when

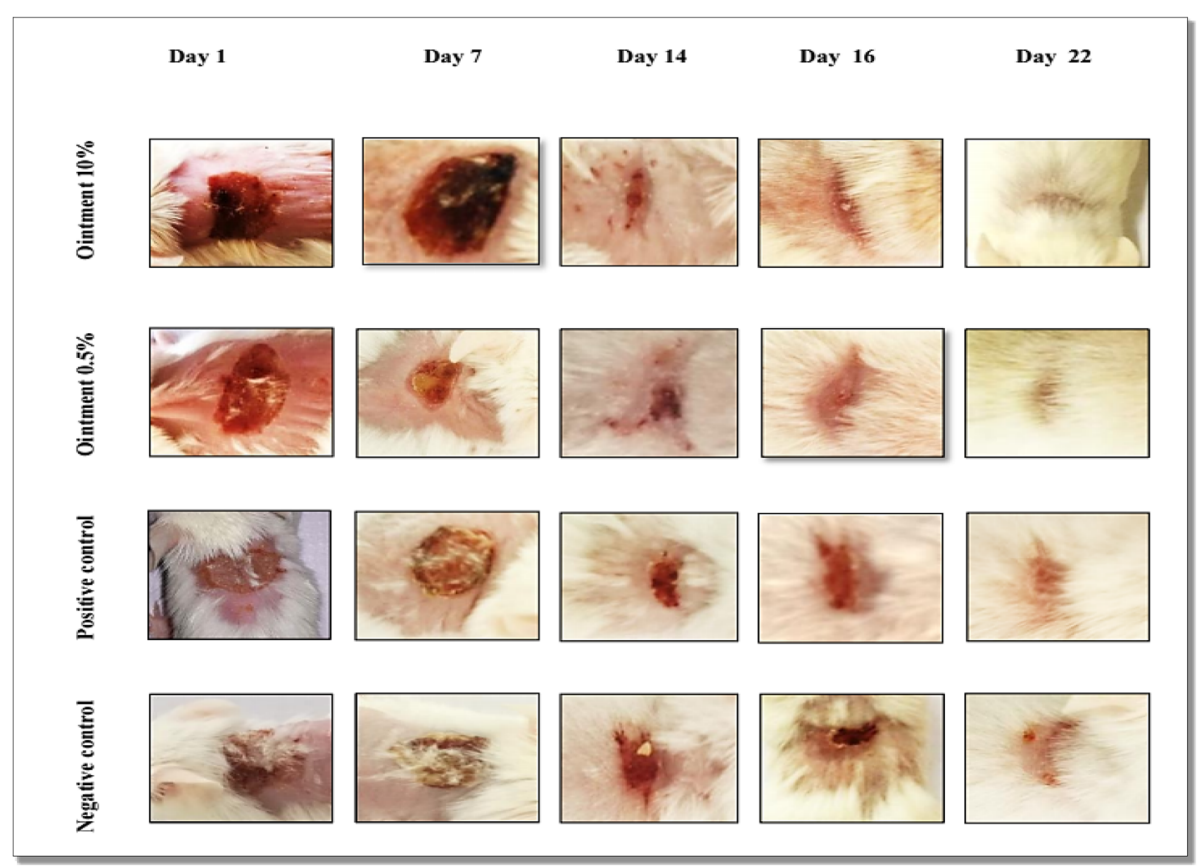

Fig. 1 Macroscopic view of wounds evolution for day 1, 7, 14, 16 and 22, treated with methanolic extract of C. reticulata (0.5\% and 10\%), silver sulfadiazine (positive control) and Vaseline (negative control) 


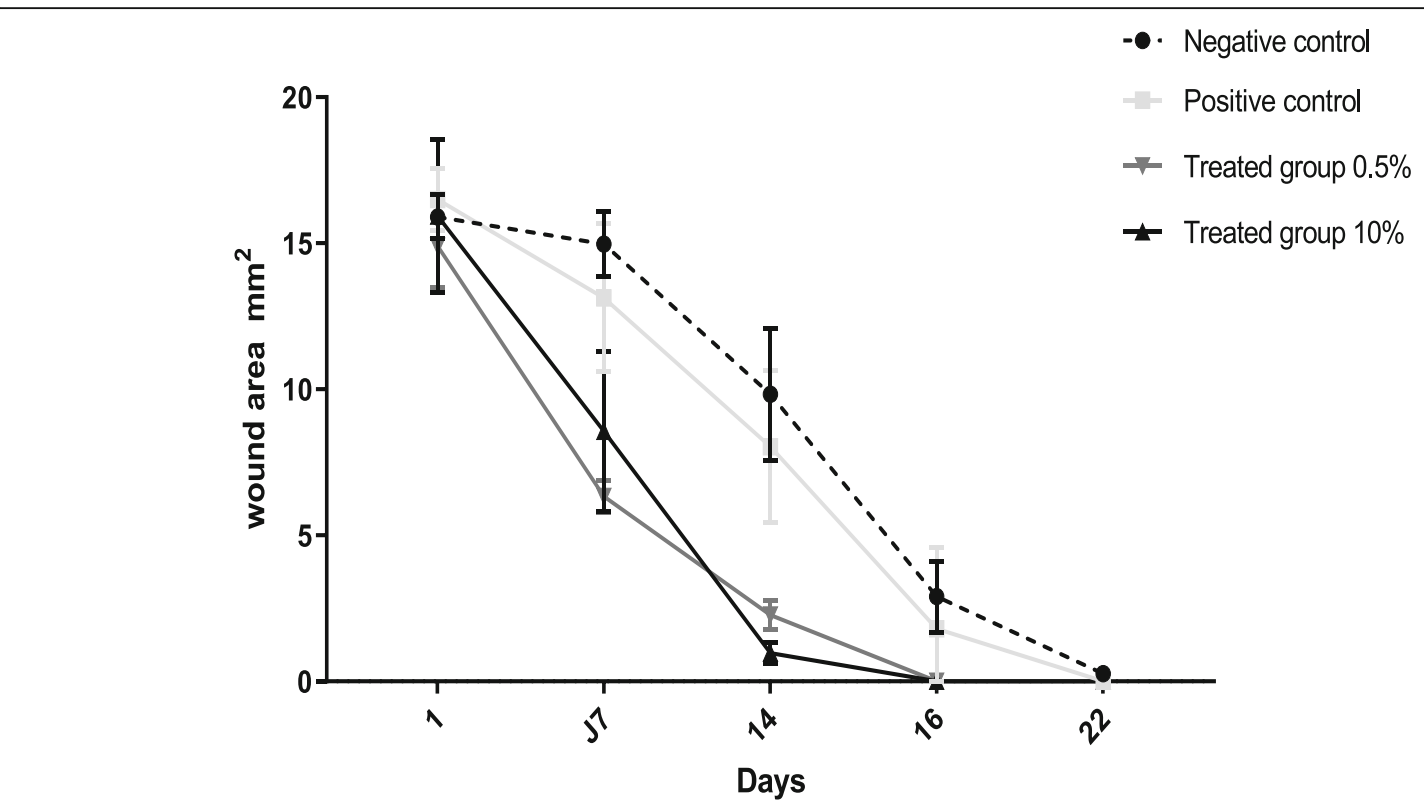

Fig. 2 Wound area reduction of animals in treated groups compared to positive and negative controls. The results were expressed as mean \pm SD $(N=3)$

compared with the negative control at the end of the study (Fig. 4). C. reticulata extract 10\% ointment formulation showed the highest amount of hydroxyproline which indicates a better wound contraction due to the increase of collagen formation and fibre stabilization on the wound site.

The methanolic extract was found to heal much faster as confirmed by enhanced rate of epithelialization and wound contraction as well as hydroxyproline and total protein content. This increase may be due to the high concentration in collagen and stabilization of the fibres [53]. The role of antioxidants has been well documented, they accelerate wound healing by decreasing the free radicals and removing products of inflammation [54]. Besides, various phytochemicals such as flavonoids, tannins, glycosides, alkaloids, saponins, sterols, terpenoids

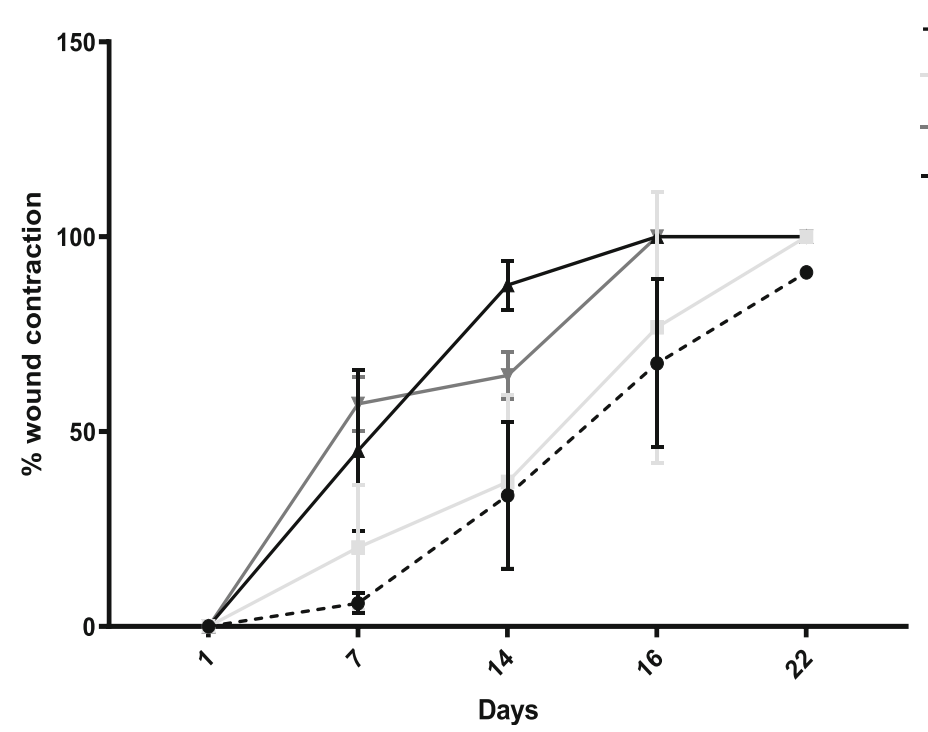

-๑. Negative control

- Positive control

$\rightarrow$ Treated group $0.5 \%$

- Treated group 10\%

Fig. 3 Effect of of C. reticulata extracts on excision wound expressed as percentage of wound contraction. The results were expressed as mean $\pm \mathrm{SD}(\mathrm{N}=3)$ 

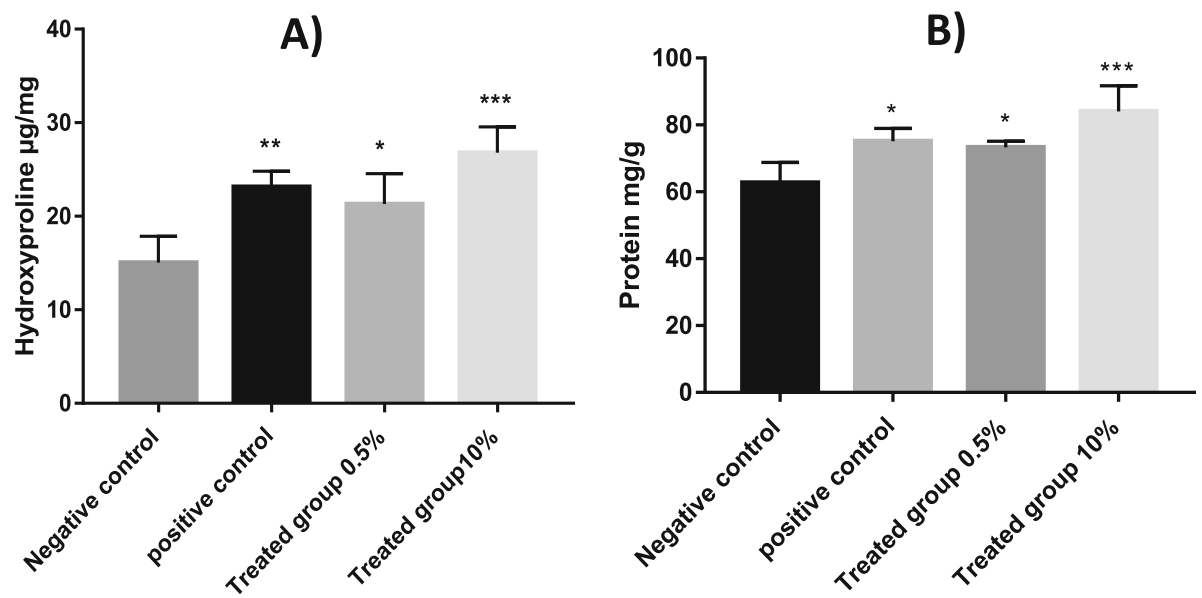

Fig. 4 Effect of C. reticulata peel extract on total protein and Hydroxyproline content. Values are expressed as mean \pm S.D. $(n=10)$. Statistical analysis done by one way ANOVA followed by Dunnet's t-test. ${ }^{*} P<0.05$; ${ }^{* *} P<0.01$ and ${ }^{* * *} P<0.001$ compared to negative control

act as therapeutic agent for the treatment of wounds and skin regeneration [55]. Furthermore, flavonoids are known to reduce lipid peroxidation not only by preventing or slowing the onset of cell necrosis but also by increasing vascularity. Hence, any drug that inhibits lipid peroxidation increase the viability of collagen fibrils by enhancing the circulation, preventing the cell damage and by improving the DNA syhthesis [56]. Moreover, the major flavonoids of citrus peel fruits are hesperidin and naringin, and another class of O-methylated aglycones of flavones like nobiletin and tangeretin in which strongly associated with therapeutic and healthy properties including antioxidant, anti-atherogenic, antiinflammatory, anti-microbial and anti-cancer effects [57, 58]. Additionally, vitamin $C$ as a powerful antioxidant is necessary for the synthesis of collagen, and enhancing the immunity of the body, it plays an important role in the wound healing process, facilitating the hydroxylation of proline and lysine for pro-collagen formation [59]. Besides, carotenoids are widespread secondary metabolites biosynthesized by plants, some of them are precursors of vitamin A [60]. It has been demonstrated that $\beta$ carotene possess the therapeutic capacity such as antiinflammatory, anti-fungal, antibacterial, anti-diabetics and wound healing $[61,62]$.

Vitamin C, A and flavonoids play beneficial role in enhancing and accelerating healing process mentioned in many previous researches $[63,64]$, their deficiencies result in impaired wound healing have been linked to reduced collagen synthesis, decreased angiogenesis, increased capillary fragility and sensitivity to wound infection $[65,66]$.

Our study revealed the presence of powerful antioxidants like flavonoids, total polyphenols, vitamin $\mathrm{C}$ and carotenoids in $C$. reticulata peel extract. These compounds possess the beneficial effects of anti-inflammation, antimicrobial and antitumor to improve the wound healing process $[51,67]$ due to their health protective and antioxidant properties. In addition, wound healing may be attributed to antibacterial effects of $C$. reticulata peel extract by destroying microbial populations such as Staphylococcus aureus suggesting this extract could be effective agent for reduction of the inflammatory cells on the wound site.

Our results were comparable to other studies on the beneficial effects of oral treatment with citrus peel extracts (C. limonum, C. paradisi and C. sinensis) on wound repair of diabetic rats skin [63]. Moreover, Ahmad et al. [68] reported that oral treatment with pomelo peel extract (PPE) had significant wound healing on induced excision skin wound in diabetic rats.

\section{Conclusion}

In our study, involving four different wound models, which included biochemical analysis, antioxidant and antimicrobial activities, indicated the wound healing activity of $0.5 \%$ and $10 \%$ ointment formulation of C. reticulata methanolic extract. The healing effects seemed to be due to the presence of substances like flavonoids, polyphenols, vitamin $\mathrm{C}$ and carotenoids that increase antioxidant activity, increased collagen deposition, hydroxyprolin formation and antibacterial activity. Hence, it may be concluded that wound healing potential of $C$. reticulata peel could be beneficial in therapeutic practice. Further studies are needed to better understand the molecular mechanisms underlying these effects.

\footnotetext{
Abbreviations

C. reticulata: Citrus reticulata; $\mid C_{50}$ : Half maximal inhibitory concentration; BHA: Butylated hydroxyanisole; PPM: Phosphomolybdate; DPPH: 2,2-diphenyl1-picrylhydrazyl; DW: Dry weight
}

Acknowledgements Not applicable. 


\section{Authors'contributions}

Sanae Dahmani: Performed the experiments; Analyzed and interpreted the data; Wrote the paper. Rachida Chabir, Lahsen El Ghadraoui: Contributed reagents, materials and provided the laboratory facilities; Faouzi Errachidi, Abdellatif Bour: revising and finalizing the corrected article; Wiam Berrada, Hafsa lansari and Meryem Benidir: participated in the conduction of the experiments. All authors read and approved the final manuscript.

\section{Funding}

This research did not receive any specific grant from funding agencies in the public, commercial, or not-for-profit sectors.

\section{Availability of data and materials}

The datasets used and analysed during the current study are available from the corresponding author on reasonable request.

\section{Ethics approval}

All Experimental rules were performed under the proper legislation of the Moroccan law and were approved by the Ethical Review Committee of Moroccan Association for Animal's Health and laboratory of Functional Ecology and Environment (n $\left.{ }^{\circ} 2-83-24\right)$, Biology Department, Faculty of Sciences and Technologies, Fez-Morocco.

\section{Consent for publication}

All authors totally agreed to the publication of the research.

\section{Competing interests}

The authors declare that they have no competing interest.

\section{Author details}

'Laboratory of Biological Testing, Team of Food and Nutrition Transition, Faculty of Sciences, Ibn Tofail University BP 133, 14000 Kenitra, Morocco. ${ }^{2}$ Laboratory of HumanPathology, Biomedicine and Environment, Team of Nutrition, Agri-Food and Environment, Faculty of Medicine and Pharmacy, Sidi Mohamed Ben Abdelah University, Km 2200 Road of Sidi Hrazem, BP $1893 \mathrm{Fez}$, Morocco. ${ }^{3}$ Laboratory of Functional Ecology and Environment, Faculty of Sciences and Technologies, Sidi Mohamed Ben Abdellah University, PO.box 2202, Route d'Imouzzer, Fez, Morocco.

Received: 1 April 2020 Accepted: 3 November 2020

Published online: 23 November 2020

\section{References}

1. Tutar U, Hepokur C, Misir S, Duman F. Antimicrobial, antioxidant, cytotoxic and wound healing effects of Thymbra sintenisii extract. Indian J Pharm Sci S. 2018;80(5):868-74.

2. Anwar F, Naseer R, Bhanger Ml, Ashraf S, Talpur FN, Aladedunye FA. Physico-chemical characteristics of citrus seeds and seed oils from Pakistan. J Am Oil Chem Soc. 2008;85:321-30.

3. Senevirathne M, Jeon YJ, Ha JH, Kim SH. Effective drying of citrus byproduct by high speed drying: A novel drying technique and their antioxidant activity. J Food Eng. 2009;92:157-63.

4. Rafiq S, Kaul R, Sofi SA, Bashir N, Nazir F, Nayik GA. Citrus peel as a source of functional ingredient: A review. J Saudi Soc Agric Sci. 2016;17:1-8.

5. Krishnappa P, Venkatarangaiah K. Venkatesh Shimoga Rajanna SK, Kayattukandy Balan R. Wound healing activity of Delonix elata stem bark extract and its isolated constituent quercetin-3-rhamnopyranosyl-(1-6) glucopyranoside in rats. J Pharm Anal. 2016:6:389-95.

6. Nejjari R, Benabbes M, Amrani M, Meddah B, Bouatia M, Taoufik J. Phytochemical screening and wound healing activity of Telephium imperati (L.) in rats. S Afr J Bot. 2019;123:147-51.

7. Padilla-Camberos E, Flores-Fernández JM, Canales-Aguirre AA, BarragánÁlvarez CP, Gutiérrez-Mercado Y, Lugo-Cervantes E. Wound healing and antioxidant capacity of Musa paradisiaca Linn. Peel extracts. JPP Res. 2016; 4(5):165-73.

8. Suguna L, Singh S, Sivakumar P, Sampath P, Chandrakasan G. Influence of Terminalia chebula on dermal wound healing in rats. Phytother Res. 2002; 16(3):227-31.

9. Yariswamy M, Shivaprasad HV, Joshi V, Nanjaraj Urs AN, Nataraju A, Vishwanath BS. Topical application of serine proteases from Wrightia tinctoria R. Br. (Apocyanaceae) latex augments healing of experimentally induced excision wound in mice. J Ethnopharmacol. 2013;149:377-83.

10. Wang Y, Beekman J, Hew J, Jackson S, Issler-Fisher AC, Parungao R, et al. Burn injury: challenges and advances in burn wound healing, infection, pain and scarring. Adv Drug Deliv Rev. 2018;123:3-17.

11. Datta HS, Mitra SK, Patwardhan B. Wound healing activity of topical application forms based on Ayurveda. Evid.-Based Complementary Altern Med. 2009;2011:1-10. https://doi.org/10.1093/ecam/nep015.

12. Barreto RS, Albuquerque-júnior RL, Adriano AA, Almeida JRGS, Santos MRV, Barreto AS, et al. A systematic review of the wound healing effects of monoterpenes and iridoid derivatives. Molecules. 2014;19:846-62.

13. Upadhyay A, Chattopadhyay P, Goyary D, Mazumder PM, Veer V. Eleutherine indica L. accelerates in vivo cutaneous wound healing by stimulating Smadmediated collagen production. J Ethnopharmacol. 2013;146:490-4.

14. Midwood KS, Williams LV, Schwarzbauer JE. Tissue repair and the dynamics of the extracellular matrix. Int J Biochem Cell B. 2004;36:1031-7.

15. Nayak SB, Lexley M, Pereira P. Catharanthus roseus flower extract has wound healing activity in Sprague dawley rats. BMC Complement Altern Med. 2006;6:41-6.

16. Gurung S, Basnet NS. Wound healing properties of Carica papaya latex: invivo evaluation in mice burn model. J Ethnopharmacol. 2009;121:338-41.

17. Odimegwu DC, Ibezim EC, Esimone CO, Nworu CS, Okoye FBC. Wound healing and antibacterial activities of the extract of Dissotis theifolia (Melastomataceae) stem formulated in a simple ointment base. J Med Plant Res. 2007;2:11-6.

18. Young A, McNaught CE. The physiology of wound healing. Surgery. 2011; 29(10):475-9.

19. Siddhuraju $\mathrm{P}$, Becker $\mathrm{K}$. Antioxidant properties of various solvent extracts of total phenolic constituents from three different agroclimatic origins of drumstick tree (Moringa oleifera lam.) leaves. J Agr Food Chem. 2003;51:2144-55.

20. Ennajjar M, Bouajila J, Lebrihi A, Mathieu F, Abderraba M, Raies A, et al. Chemical composition and antimicrobial and antioxidant activities of essential oils and various extracts of Juniperus phoenicea L. (Cupressacees). J Food Sci. 2009;74:364-71.

21. Barros L, Calhelha RC, Vaz JA, Ferreira ICFR, Baptista P, Estevinho LM. Antimicrobial activity and bioactive compounds of Portuguese wild edible mushrooms methanolic extracts. Eur Food Res Technol. 2007:225:151-6.

22. Barros L, Carvalho AM, Ferreira CFRI. Exotic fruits as a source of important phytochemicals: improving the traditional use of Rosa canina fruits in Portugal. Food Res Int. 2011;44(7):2233-6.

23. Barros L, Carvalho AM, Ferreira CFRI. Leaves. Flowers. Immature fruits and leafy flowered stems of Malvasylvestris: a comparative study of the nutraceutical potential and composition. Food Chem Toxicol. 2010;48(6): $1466-72$.

24. Lee HS, Castle WS, Coates GA. High-performance liquid chromatography for the characterization of carotenoids in the new sweet orange (Earlygold) grown in Florida. USA J Chromatogr A. 2001;913:371-7.

25. Kumar R, Vijay S, Khan N. Comparative nutritional analysis and antioxidant activity of fruit juices of some citrus spp. Octa J Biosci. 2013;1 (1):44-53.

26. Bligh EG, Dyer WJ. A rapid method for total lipid extraction and purification. Can J Biochem Physiol. 1959;37:911-7.

27. Ellouze I, Debbabi H, Belkacem A, Rekik B. Variation in physicochemical and sensory quality of sour orange (Citrus aurantium L.) marmalade from the Cap Bon region in North-East Tunisia. EDP Sci. 2011;66:315-25.

28. Loizzo MR, Menichini F, Conforti F, Tundis R, Bonesi M, Saab M, et al. Chemical analysis, antioxidant, antiinflammatory and anticholinesterase activities of Origanum ehrenbergii Boiss and Origanum syriacum L. essential oils. Food Chem. 2009;117:174-80.

29. Prieto P, Pineda M, Aguilar M. Spectrophotometric quantitation of antioxidant capacity through the formation of a phosphomolybdenum complex: specific application to the determination of vitamin E. Anal Biochem. 1999;269:337-41.

30. Mourey M, Mortier F, Mourey A. Activité antimicrobienne des extraits de feuilles de Gingko biloba L. Plant Méd Phytothér. 2007;19:270-6.

31. Pirbalouti AG, Yousefi M, Nazari H, Karimi I, Koohpayeh A. Evaluation of burn healing properties of Arnebia euchroma and Malva sylvestris. E J Bio. 2009;5:62-6.

32. Latif MA, Zaki MZ, Leng TM, Abdul Rahman NH, Arshad SA, A Hamid A. Alocasia denudata Engler treatment enhance open wound healing activities in Wistar rat's skin. J Ethnopharmacol. 2015;176:258-67.

33. Tung $\mathrm{P}$, Cheng $\mathrm{H}$. An improved method for the determination of hydroxyproline in rat skin. J Invest Dermatol. 1969:112-5. https://doi.org/10. 1038/jid.1969.116 
34. Wang H, Chen G, Guo X, Abbasi AM, Liu RH. Influence of the stage of ripeness on the phytochemical profiles, antioxidant and anti-proliferative activities in different parts of Citrus reticulata Blanco CV. Chachiensis. LWTFood Sci Techn. 2016;69:67-75.

35. Zhang H, Yang YF, Zhou ZQ. Phenolic and flavonoid contents of mandarin (Citrus reticulata Blanco) fruit tissues and their antioxidant capacity as evaluated by DPPH and ABTS methods. Inter J Integr Agric. 2018;17(1):256-63.

36. Chen X, Yuan K, Liu H. Phenolic contents and antioxidant activities in ethanol extracts of citrus reticulata Blanco CV. Ougan fruit. J Food Agric Environ. 2010;8(2):150-5

37. Yang C, Gundala SR, Mukkavilli R, et al. Synergistic interactions among flavonoids and acetogenins in Graviola (Annona muricata) leaves confer protection against prostate cancer. J Carcinog. 2015;36(6):656-65.

38. Brickman AM, Khan UA, Provenzano FA, Yeung LK, Suzuki W, Schroeter H, et al. Enhancing dentate gyrus function with dietary flavanols improves cognition in older adults. Nature Neurosci. 2014;17(12):1798-803.

39. Gropper SS, Smith JL, Groff JM. Advanced nutrition and human metabolism: Wardsworth group, USA. $4^{\text {th }}$ ed; 2005. p. 101-5.

40. Barros HRDM, Ferreira TAPDC, Genovese MI. Antioxidant capacity and mineral content of pulp and peel from commercial cultivars of citrus from Brazil. Food Chem. 2012:134:1892-8.

41. Wang YC, Chuang YC, Hsu HW. The flavonoid, carotenoid and pectin content in peels of citrus cultivated in Taiwan. Food Chem. 2008;106(1):277-84.

42. Institute of Medicine. Protein and amino acids. In: Dietary Reference Intakes for Energy, Carbohydrate, Fiber, Fat, Fatty Acids, Cholesterol, Protein, and Amino Acids (Macronutrients). Washington, DC: National Academies Press; 2005. p. 593-4.

43. Lovina G, Kaushal S. Evaluation of chemical composition and antioxidant potential of essential oil from Citrus reticulata fruit peels. J Adv Res. 2018; 15(2):1-9.

44. Ghanem N, Mihoubi D, Kechaoua N, Boudhrioua MN. Microwave dehydration of three citrus peel cultivars: effect on water and oil retention capacities, color, shrinkage and total phenols content. Ind Crop Prod. 2012 40:167-77

45. Causse M, Chervin C, Mauget JC, Renard C. Les sources de variabilité des qualités nutritionnelles des fruits et légumes (Chapitre 2). Paris: Institut National de la Recherche Agronomique; 2007. p. 63.

46. M'hiri N, loannou I, Ghoul M, Mihoubi BN. Extraction methods of citrus peel phenolic compounds. Food Rev Int. 2014:265-90. https://doi.org/10.1080/ 87559129 .

47. Ghasemi KY, Ghasemi Y, Ebrahim Zadeh MA. Antioxidant activity, phenol and flavonoid contents of 13 citrus species peels and tissues. Pak J Pharm Sci. 2009:22:277-81.

48. Chen XM, Tait AR, Kitts D. Flavonoid composition of orange peel and its association with antioxidant and anti-inflammatory activities. Food Chem. 2017;218:15-21.

49. Gironés-Vilaplana A, Mena P, García-Viguera C, Moreno DA. A novel beverage rich in antioxidant phenolics: Maqui berry (Aristotelia chilensis) band lemon juice. LWT-Food Sci Techn. 2012:47:279-86.

50. Sharma S, Kori S, Parmar A. Surfactant mediated extraction of total phenolic contents (TPC) and antioxidants from fruits juices. Food Chem. 2015;185: 284-8.

51. Mathur A, Verma SK, Purohit R, Gupta V, Dua VK, Prasad GBKS, Mathur D, Singh SK, Singh S. Evaluation of in vitro antimicrobial and antioxidant activities of peel and pulp of some citrus fruits. J Biotechnol Biother. 2011; $1(2): 1-16$.

52. Shakya A, Luitel B, Kumari P, Devkota R, Raj Dahal P, Chaudhary R. Comparative study of antibacterial activity of juice and peel extract of citrus fruits. J Microbiol. 2019;6(1):82-8.

53. Jayasutha J, Monic J, Nithila S. Evaluation of wound healing activity of ethanolic extract of Aristolochia bracteata and Cassia tora on wistar albino rats. Int J Pharmtech Res. 2011;3:1547-50.

54. Pereira A, Maraschin M. Banana (Musa spp) from peel to pulp: Ethnopharmacology source of bioactive compounds and its relevance for human health. J Ethnopharmacol. 2015;160:149-63.

55. Thakur R, Jain N, Pathak R, Sandhu SS. Practices in wound healing studies of plants. Evid.-Based Complementary Altern Med. 2011:1-17. https://doi.org/ 10.1155/2011/438056.

56. Getie M, Gebre-Mariam T, Rietz R, Neubert RH. Evaluation of the release profiles of flavonoids from topical formulations of the crude extract of the leaves of Dodonea viscosa (Sapindaceae). Pharmazie. 2002;57(5):320-2.
57. Caengprasath N, Ngamukote S, Mäkynen K, Adisakwattana S. The protective effects of pomelo peel extract (Citrus grandis L. osbeck) against fructosemediated protein oxidation and glycation. Food Funct. 2013;4(6):491-502.

58. Lai C, Li S, Miyauchi Y, Suzawa M, Ho CT, Pan MH. Potent anti-cancer effects of citrus peel flavonoids in human prostate xenograft tumors. Food Funct. 2013:4:944-9. https://doi.org/10.1039/c3fo60037h.

59. Ronchetti IP, Quaglino D, Bergamini G. Ascorbic acid and connective tissue. Subcell Biochem. 1996:25:249-64.

60. Tang G, Russell RM. Carotenoids as Provitamin A. In: Britton G., Pfander H., Liaaen-Jensen S. (eds) Carotenoids. Carotenoids. Birkhñuser Basel; 2009;5: 149-72.

61. Akkol EK, Koca U, Pesin I, Yilmazer D, Toker G, Yeşilada E. Exploring the wound healing activity of Arnebia densiflora (Nordm) Ledeb. By in vivo models. J Ethnopharmacol. 2009;124:137-41.

62. Nayak BS, Sandiford S, Maxwell A. Evaluation of the wound healing activity of ethanolic extract of Morinda citrifolia L leaf. Evid-Based Complementary Altern Med. 2009;6:351-6.

63. Ahmad M, Ansari MN, Alam A, Khan TH. Oral dose of citrus peel extracts promotes wound repair in diabetic rats. Pak J Pharm Sci. 2013;16(20):108694

64. Lodhi S, Singhai AK. Wound healing effect of flavonoid rich fraction and lutein isolated from Martynia annua Linn. On streptozotocin induced diabetic rats. Asian Pac J Trop Biomed. 2013;6:253-9.

65. Arnold M, Barbul A. Nutrition and wound healing. Plast Reconstr. 2006;117: 42-58.

66. Campos AC, Groth AK, Branco AB. Assessment and nutritional aspects of wound healing. Curr Opin Clin Nutr Metab Care. 2008;11(3):281-8.

67. Romagnolo DF, Selmin OI. Flavonoids and cancer prevention. A review of the Evid. J Nutr Gerontol Geriatr. 2012;31(3):206-38.

68. Ahmad AA, Al Khalifa II, Abudayeh ZH. The role of pomelo peel extract for experimentally induced wound in diabetic rats. Pharmacogn J. 2018;10:885-91.

\section{Publisher's Note}

Springer Nature remains neutral with regard to jurisdictional claims in published maps and institutional affiliations.

\section{Submit your manuscript to a SpringerOpen ${ }^{\circ}$ journal and benefit from:}

- Convenient online submission

- Rigorous peer review

- Open access: articles freely available online

- High visibility within the field

Retaining the copyright to your article

Submit your next manuscript at $>$ springeropen.com 